Supporting Information

\title{
Ultrasensitive determination of rare modified cytosines based on novel hydrazine labelling reagents
}

Yue Yu ${ }^{1}$, Fang Yuan ${ }^{1}$, Xiao-Hui Zhang ${ }^{2}$, Ming-Zhe Zhao ${ }^{3}$,Ying-Lin Zhou ${ }^{1, *}$ and Xin-Xiang

\section{Zhang ${ }^{1}$}

1 Beijing National Laboratory for Molecular Sciences (BNLMS), MOE Key Laboratory of Bioorganic Chemistry and Molecular Engineering, College of Chemistry and Molecular Engineering, Peking University, Beijing 100871, China.

2 State Key Laboratory of Natural and Biomimetic Drugs, Peking University, 38 Xueyuan Road, Beijing 100191, China.

3 Capital Normal University High School, No.33 Beiwa Road, Haidian District, Beijing, 100048, China.

*Tel: +86-10-62754112; Fax: +86-10-62754112; Email: zhouyl@pku.edu.cn. 


\section{Contents}

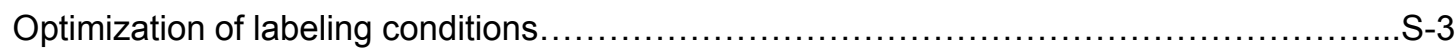

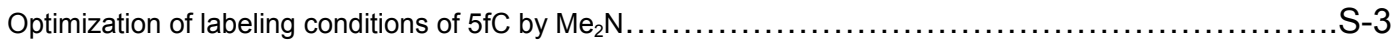

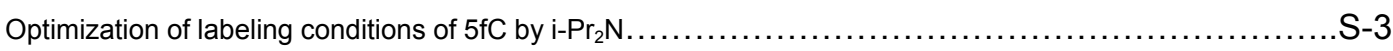

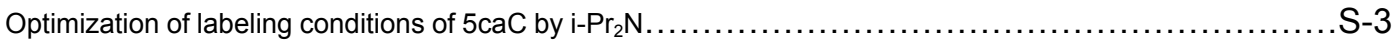

Table S1 The MRM transitions and optimal parameters for the analysis by LC-MS/MS......S-4

Table S2 LODs of $5 \mathrm{fC}$ and $5 \mathrm{caC}$ with and without chemical labeling ........................ 5

Table S3 Comparison of the LODs with different analytical methods........................ S-6

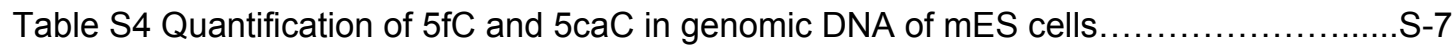

Table S5 Accuracy and reproducibility for the determination of $5 \mathrm{fC}$ and $5 \mathrm{caC} \ldots \ldots \ldots \ldots \ldots . . . . .8$

Table S6 Quantification of $5 \mathrm{mC}, 5 \mathrm{hmC}, 5 \mathrm{fC}$ and $5 \mathrm{caC}$ in mouse tissues....................... 9

Figure S1 Product ions spectra of $5 \mathrm{fC}$ labelled by $\mathrm{Me}_{2} \mathrm{~N}, \mathrm{Et}_{2} \mathrm{~N}$, and $\mathrm{i}-\mathrm{Pr}_{2} \mathrm{~N} \ldots \ldots \ldots \ldots \ldots \ldots \ldots$ S-10

Figure S2 Optimization of derivatization conditions for $5 \mathrm{fC}$ by $\mathrm{Et}_{2} \mathrm{~N} \ldots \ldots \ldots \ldots \ldots \ldots \ldots \ldots . . . . . .11$

Figure S3 Optimization of derivatization conditions for $5 \mathrm{fC}$ by $\mathrm{Me}_{2} \mathrm{~N} \ldots \ldots \ldots \ldots \ldots \ldots \ldots . . . . .12$

Figure S4 Optimization of derivatization conditions for $5 \mathrm{fC}$ by $\mathrm{i}-\mathrm{Pr}_{2} \mathrm{~N} \ldots \ldots \ldots \ldots \ldots \ldots \ldots . . . . . .13$

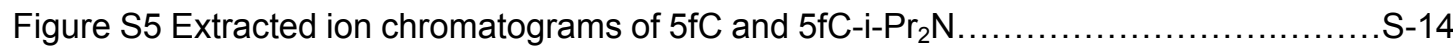

Figure S6 Optimization of derivatization conditions for $5 \mathrm{caC}$ by $\mathrm{i}-\mathrm{Pr}_{2} \mathrm{~N} \ldots \ldots \ldots \ldots \ldots \ldots \ldots . \mathrm{S}-15$

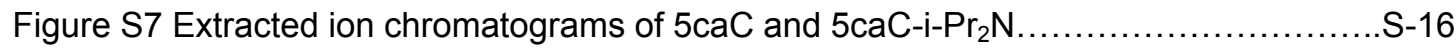

Figure S8 Extracted ion chromatograms of $5 \mathrm{caC}-\mathrm{i}-\mathrm{Pr}_{2} \mathrm{~N}, \mathrm{i}-\mathrm{Pr}_{2} \mathrm{~N}$ and $5 \mathrm{fC}-\mathrm{i}-\mathrm{Pr}_{2} \mathrm{~N} \ldots \ldots \ldots \ldots \ldots \ldots . . . \mathrm{S}-17$

Figure S9 Extracted ion chromatograms of DNA samples................................ 18

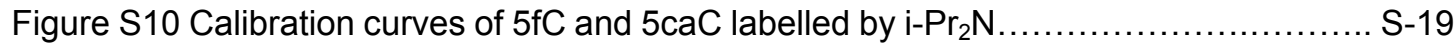

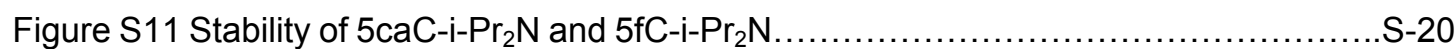

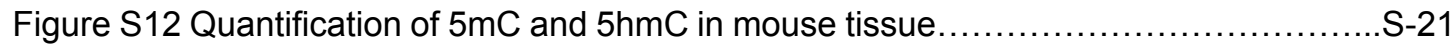




\section{Optimization of labeling conditions of $5 \mathrm{fC}$ by $\mathrm{Me}_{2} \mathrm{~N}$}

We optimized the labeling conditions of $5 \mathrm{fC}$ by $\mathrm{Me}_{2} \mathrm{~N}$. As for reaction time, the largest peak area can be achieved only by votexing without additional reaction time at room temperature. As for concentration of $\mathrm{Me}_{2} \mathrm{~N}$, our results indicated that $5 \mathrm{mM} \mathrm{Me}{ }_{2} \mathrm{~N}$ was sufficient for the chemical labeling (Figure S3).

\section{Optimization of labeling conditions of $5 \mathrm{fC}$ by i- $\mathrm{Pr}_{2} \mathrm{~N}$}

We optimized the labeling conditions of $5 f C$ by i- $\operatorname{Pr}_{2} \mathrm{~N}$. As for reaction time, the largest peak area can be achieved only by votexing without additional reaction time at room temperature. As for concentration of $\mathrm{i}-\mathrm{Pr}_{2} \mathrm{~N}$, our results indicated that $5 \mathrm{mM}$ i- $-\mathrm{Pr}_{2} \mathrm{~N}$ was sufficient for the chemical labeling (Figure S4).

\section{Optimization of labeling conditions of $5 \mathrm{caC}$ by $\mathrm{i}-\mathrm{Pr}_{2} \mathrm{~N}$}

We optimized the labeling conditions of $5 \mathrm{caC}$ by $\mathrm{i}-\mathrm{Pr}_{2} \mathrm{~N}$. We first investigated reaction time ranging from 0 to $60 \mathrm{~min}$. Generally, $50 \mathrm{nM} \mathrm{5fC}, 10 \mathrm{nM} \mathrm{caC}$ and $50 \mathrm{mM}$ i- $\mathrm{Pr}_{2} \mathrm{~N}$ were dissolved in $50 \% \mathrm{ACN}$, and then $2 \mathrm{mg} \mathrm{mL}^{-1} \mathrm{HOBT}$ dissolved in $\mathrm{ACN}$ and $150 \mathrm{mg} \mathrm{mL}^{-1} \mathrm{EDC}$ dissolved in water were added into the mixture followed by incubation at $37^{\circ} \mathrm{C}$. The results demonstrated that $30 \mathrm{~min}$ was sufficient for the chemical labeling (Figure S5A). Then, the reaction temperature was optimized in the range from 15 to $55^{\circ} \mathrm{C}$. The results indicated that $37^{\circ} \mathrm{C}$ was appropriate to obtain good chemical labeling (Figure S5B). The concentration of $\mathrm{i}-\mathrm{Pr}_{2} \mathrm{~N}$ was also optimized, and the results showed that $5 \mathrm{mM}$ i- $-\mathrm{Pr}_{2} \mathrm{~N}$ was sufficient for the chemical labeling (Figure S5C). As for the concentration of EDC, our results indicated that $50 \mathrm{mg} \mathrm{mL}^{-1}$ EDC was appropriate to obtain good chemical labeling (Figure S5D). Finally, we optimized the concentration of HOBT, and the results demonstrated that $4 \mathrm{mg} \mathrm{mL}^{-1} \mathrm{HOBT}$ was sufficient for the chemical labeling (Figure S5E). Taken together, the optimized conditions for $5 \mathrm{caC}$ by i- $\mathrm{Pr}_{2} \mathrm{~N}$ were under $37^{\circ} \mathrm{C}$ for 30 min with $5 \mathrm{mM} \mathrm{i-Pr}{ }_{2} \mathrm{~N}, 50 \mathrm{mg} \mathrm{mL}^{-1} \mathrm{EDC}$ and $4 \mathrm{mg} \mathrm{mL}^{-1} \mathrm{HOBT}$. 
Table S1 The MRM transitions and optimal parameters for the analysis by LC-MS/MS.

\begin{tabular}{|c|c|c|c|c|c|}
\hline Analyte & $\begin{array}{c}\text { Precursor ion } \\
(\mathrm{Q} 1)\end{array}$ & $\begin{array}{c}\text { Product ion } \\
(\mathrm{Q} 3)\end{array}$ & $\begin{array}{c}\text { Collision } \\
\text { energy } \\
(\mathrm{CE})\end{array}$ & $\begin{array}{c}\text { Collision cell exit } \\
\text { potential } \\
(\mathrm{CXP})\end{array}$ & $\begin{array}{c}\text { Retention } \\
\text { time } \\
(\min )\end{array}$ \\
\hline $5 \mathrm{fC}$ & 256.1 & 140.1 & 18 & 10.0 & 5.68 \\
\hline $5 \mathrm{fC}-\mathrm{Me}_{2} \mathrm{~N}$ & 435.2 & 319.3 & 19 & 20.0 & 8.48 \\
\hline $5 \mathrm{fC}-\mathrm{Et}_{2} \mathrm{~N}$ & 491.3 & 375.3 & 22 & 10.3 & 9.72 \\
\hline $5 \mathrm{fC}-\mathrm{i}-\mathrm{Pr}_{2} \mathrm{~N}$ & 547.3 & 431.2 & 31 & 11.0 & 12.38 \\
\hline $5 \mathrm{caC}$ & 272.1 & 156.1 & 15 & 14.0 & 3.01 \\
\hline $5 \mathrm{caC}-\mathrm{i}-\mathrm{Pr}_{2} \mathrm{~N}$ & 563.4 & 447.3 & 28 & 22.0 & 10.02 \\
\hline $\mathrm{C}$ & 228.1 & 112.0 & 17 & 10.0 & 1.81 \\
\hline $5 \mathrm{mC}$ & 242.1 & 126.1 & 16 & 10.0 & 3.26 \\
\hline $5 \mathrm{hmC}$ & 258.0 & 142.1 & 15 & 12.0 & 2.03 \\
\hline $\mathrm{A}$ & 252.1 & 136.1 & 17 & 15.0 & 7.23 \\
\hline $\mathrm{T}$ & 243.1 & 127.1 & 16 & 20.0 & 7.89 \\
\hline $\mathrm{G}$ & 268.1 & 152.1 & 20 & 15.0 & 6.51 \\
\hline
\end{tabular}


Table S2 Limits of detection (LODs) of $5 \mathrm{fC}$ and $5 \mathrm{caC}$ with and without chemical labeling.

\begin{tabular}{|c|c|c|}
\hline \multirow{2}{*}{} & \multicolumn{2}{|c|}{ LODs } \\
\cline { 2 - 3 } & $5 \mathrm{fC}$ & $5 \mathrm{caC}$ \\
\hline Without labelling & $1.25 \mathrm{fmol}$ & $2.5 \mathrm{fmol}$ \\
\hline $\mathrm{Me}_{2} \mathrm{~N}$ labelling & $50 \mathrm{amol}$ & $/$ \\
\hline $\mathrm{Et}_{2} \mathrm{~N}$ labelling & $12.5 \mathrm{amol}$ & $/$ \\
\hline $\mathrm{i}-\mathrm{Pr}_{2} \mathrm{~N}$ labelling & $10 \mathrm{amol}$ & $25 \mathrm{amol}$ \\
\hline
\end{tabular}


Table S3 Comparison of the LODs of $5 \mathrm{fC}$ and $5 \mathrm{caC}$ obtained in different analytical methods.

\begin{tabular}{|l|l|l|l|l|}
\hline \multirow{2}{*}{ Detection Methods } & \multicolumn{2}{|c|}{ LODs } & \multirow{2}{*}{ Biological samples } & Reference \\
\cline { 2 - 5 } & $5 \mathrm{fC}$ & $5 \mathrm{caC}$ & $20 \mu \mathrm{g}$ & $(1)$ \\
\hline LC-MS/MS & $5 \mathrm{fmol}$ & $10 \mathrm{fmol}$ & $30-80 \mu \mathrm{g}$ & $(2)$ \\
\hline LC-MS/MS/MS & $98 \mathrm{amol}$ & $140 \mathrm{amol}$ & $10 \mu \mathrm{g}$ & $(3)$ \\
\hline $\begin{array}{l}\text { LC-MS/MS with BDAPE } \\
\text { derivatization }\end{array}$ & $110 \mathrm{amol}$ & $230 \mathrm{amol}$ & $30-100 \mu \mathrm{g}$ & $(4)$ \\
\hline $\begin{array}{l}\text { Two-dimensional- } \\
\text { UPLC-MS/MS }\end{array}$ & $300 \mathrm{amol}$ & $50 \mathrm{amol}$ & $600 \mathrm{ng}$ & This work \\
\hline $\begin{array}{l}\text { LC-MS/MS with i- } \mathrm{Pr}_{2} \mathrm{~N} \\
\text { derivatization }\end{array}$ & $10 \mathrm{amol}$ & $25 \mathrm{amol}$ & &
\end{tabular}


Table S4 Quantification of $5 \mathrm{fC}$ and $5 \mathrm{caC}$ in genomic DNA of mES cells.

\begin{tabular}{|c|c|c|c|}
\hline Content $\left(5 \mathrm{fC} / 10^{6} \mathrm{G}\right)$ & $\begin{array}{c}\text { Average content } \\
\left(5 \mathrm{fC} / 10^{6} \mathrm{G}\right)\end{array}$ & $\begin{array}{c}\text { Content } \\
\left(5 \mathrm{caC} / 10^{6} \mathrm{G}\right)\end{array}$ & $\begin{array}{c}\text { Average content } \\
\left(5 \mathrm{caC} / 10^{6} \mathrm{G}\right)\end{array}$ \\
\cline { 1 - 1 } & \multirow{3}{*}{16.2} & 2.2 & \multirow{2}{*}{$2.4 \pm 0.5$} \\
\cline { 1 - 1 } & \multirow{2}{*}{16.8} & 2.0 & \\
\cline { 1 - 1 } & & 2.9 & \\
\cline { 1 - 1 } & & \multicolumn{2}{|c}{} \\
\cline { 1 - 1 } & &
\end{tabular}


Table S5 Accuracy and reproducibility for the determination of $5 \mathrm{fC}$ and $5 \mathrm{caC}$ by i- $\mathrm{Pr}_{2} \mathrm{~N}$ labelling coupled with LC-MS/MS analysis.

\begin{tabular}{|c|c|c|c|c|c|c|c|}
\hline & & \multicolumn{3}{|c|}{$5 \mathrm{fC}$} & \multicolumn{3}{|c|}{$5 \mathrm{caC}$} \\
\hline & $\begin{array}{c}\text { Theoretical } \\
\text { concentrations (pM) }\end{array}$ & $\begin{array}{c}5.0 \\
\text { (Low) }\end{array}$ & $\begin{array}{c}100.0 \\
\text { (Medium) }\end{array}$ & $\begin{array}{l}800.0 \\
\text { (High) }\end{array}$ & $\begin{array}{c}5.0 \\
\text { (Low) }\end{array}$ & $\begin{array}{c}50.0 \\
\text { (Medium) }\end{array}$ & $\begin{array}{l}400.0 \\
\text { (High) }\end{array}$ \\
\hline \multirow{3}{*}{$\begin{array}{l}\text { Day } 1 \\
(n=3)\end{array}$} & $\begin{array}{c}\text { Measured mean } \\
\text { concentrations (pM) }\end{array}$ & 5.4 & 105.6 & 839.2 & 4.6 & 53.8 & 398.8 \\
\hline & $\begin{array}{l}\text { RSD (\%) } \\
\quad(n=3)\end{array}$ & 1.8 & 3.7 & 4.6 & 5.3 & 0.6 & 3.4 \\
\hline & RE (\%) & 8.8 & 5.6 & 4.9 & -7.9 & 7.6 & -0.3 \\
\hline \multirow{3}{*}{$\begin{array}{l}\text { Day } 2 \\
(n=3)\end{array}$} & $\begin{array}{c}\text { Measured mean } \\
\text { concentrations (pM) }\end{array}$ & 5.5 & 107.1 & 808.9 & 4.6 & 53.4 & 414.9 \\
\hline & $\begin{array}{c}\text { RSD }(\%) \\
\quad(n=3)\end{array}$ & 3.6 & 1.9 & 3.2 & 5.7 & 4.9 & 2.8 \\
\hline & RE (\%) & 10.6 & 7.1 & 1.1 & -7.7 & 6.8 & 3.7 \\
\hline \multirow{3}{*}{$\begin{array}{l}\text { Day } 3 \\
(n=3)\end{array}$} & $\begin{array}{c}\text { Measured mean } \\
\text { concentrations (pM) }\end{array}$ & 4.7 & 106.8 & 829.7 & 4.5 & 50.9 & 399.5 \\
\hline & $\begin{array}{l}\text { RSD (\%) } \\
\quad(n=3)\end{array}$ & 4.6 & 2.6 & 3.9 & 5.2 & 5.6 & 7.7 \\
\hline & RE (\%) & -6.9 & 6.8 & 3.7 & -11.1 & 1.9 & -0.1 \\
\hline
\end{tabular}


Table S6 Quantification of $5 \mathrm{mC}, 5 \mathrm{hmC}, 5 \mathrm{fC}$ and $5 \mathrm{caC}$ in mouse tissues.

\begin{tabular}{|c|c|c|c|c|}
\hline & $5 \mathrm{mC} / 10^{2} \mathrm{C}$ & $5 \mathrm{hmC} / 10^{3}(\mathrm{C}+5 \mathrm{mC})$ & $5 \mathrm{fC} / 10^{6} \mathrm{G}$ & $5 \mathrm{caC} / 10^{7} \mathrm{G}$ \\
\hline \multirow{3}{*}{ Brain } & 4.04 & 6.99 & 4.78 & 3.44 \\
\hline & 3.92 & 7.67 & 3.84 & 6.52 \\
\hline & 4.07 & 7.49 & 2.89 & 6.28 \\
\hline \multirow{3}{*}{ Cerebellum } & 5.76 & 4.10 & 1.59 & 1.38 \\
\hline & 3.96 & 3.75 & 2.67 & 3.70 \\
\hline & 4.98 & 3.77 & 2.84 & 4.14 \\
\hline \multirow{3}{*}{ Lung } & 4.08 & 3.17 & 0.83 & 2.53 \\
\hline & 4.25 & 2.23 & 1.13 & 3.93 \\
\hline & 3.91 & 2.04 & 0.52 & 4.30 \\
\hline \multirow{3}{*}{ Kidney } & 3.96 & 2.27 & 0.55 & 1.51 \\
\hline & 4.75 & 2.18 & 0.48 & 3.44 \\
\hline & 4.13 & 2.37 & 0.56 & 3.26 \\
\hline \multirow{3}{*}{ Liver } & 4.35 & 2.70 & 3.06 & 2.80 \\
\hline & 4.28 & 1.82 & 3.00 & 5.40 \\
\hline & 2.90 & 1.85 & 3.28 & 5.36 \\
\hline \multirow{3}{*}{ Heart } & 3.70 & 1.91 & 1.80 & 2.20 \\
\hline & 3.60 & 1.86 & 1.24 & 3.03 \\
\hline & 3.72 & 1.98 & 0.77 & 3.65 \\
\hline \multirow{3}{*}{ Pancreas } & 5.67 & 1.47 & 0.96 & 1.89 \\
\hline & 4.30 & 1.60 & 0.48 & 4.23 \\
\hline & 3.69 & 1.12 & 0.69 & 4.35 \\
\hline \multirow{3}{*}{ Stomach } & 5.14 & 1.53 & 0.75 & 1.94 \\
\hline & 5.19 & 1.25 & 0.93 & 3.32 \\
\hline & 5.25 & 1.23 & 1.13 & 4.21 \\
\hline \multirow{3}{*}{ Prostate } & 3.97 & 1.60 & 0.36 & 1.14 \\
\hline & 4.22 & 1.52 & 0.39 & 2.96 \\
\hline & 4.14 & 1.56 & 1.13 & 4.72 \\
\hline \multirow{3}{*}{ Spleen } & 5.20 & 0.71 & 2.72 & 4.45 \\
\hline & 4.11 & 0.44 & 3.67 & 5.61 \\
\hline & 4.66 & 0.62 & 2.12 & 5.93 \\
\hline
\end{tabular}




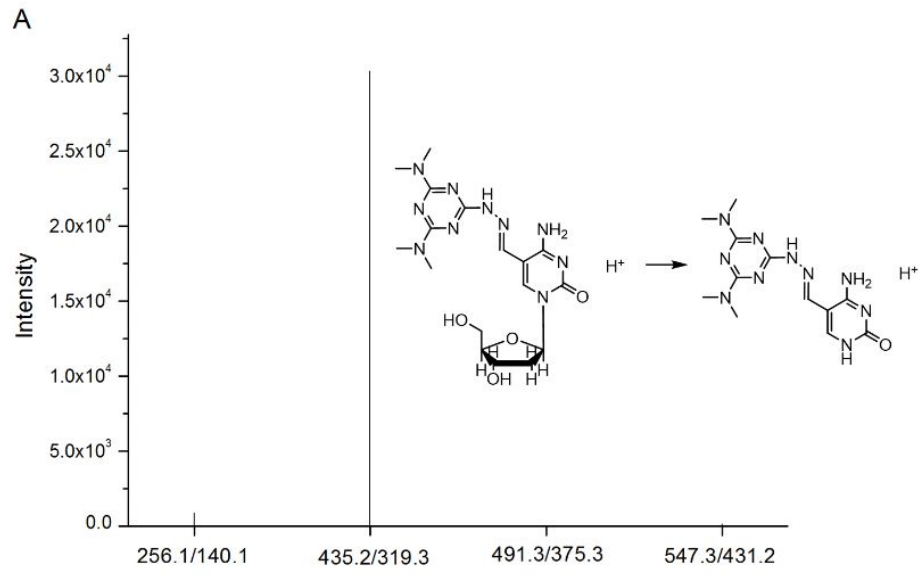

B

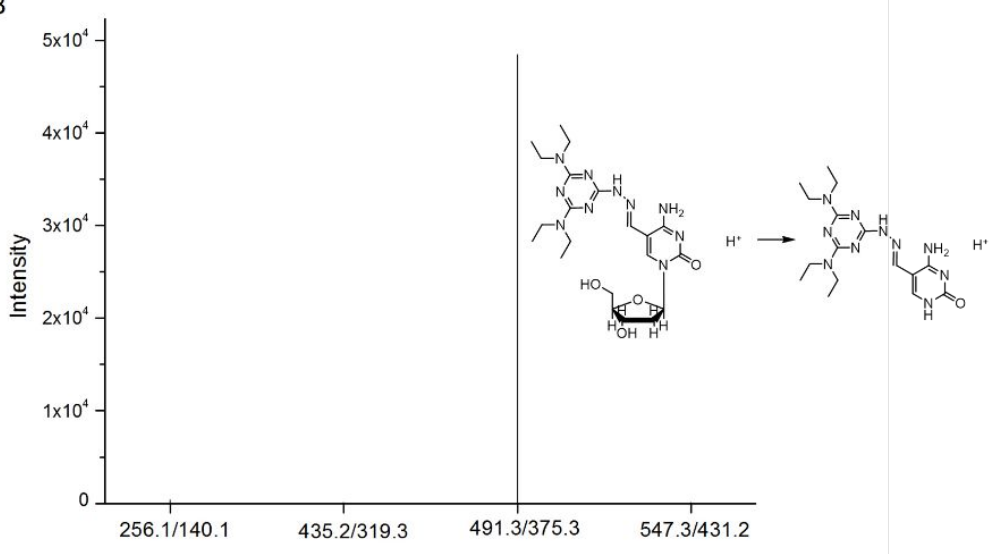

C

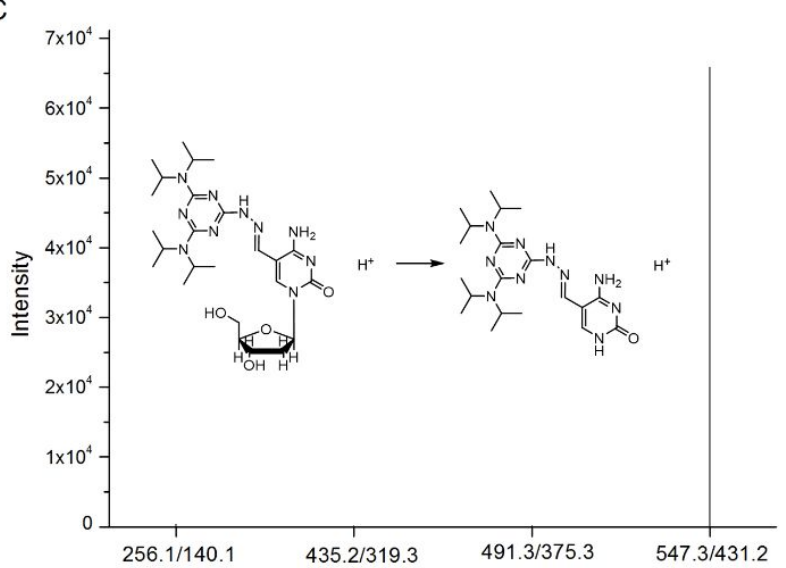

Figure S1 Product ions spectra of $5 f C$ labelled by (A) $\mathrm{Me}_{2} \mathrm{~N}$, (B) $\mathrm{Et}{ }_{2} \mathrm{~N}$, and (C) $\mathrm{i}-\mathrm{Pr}_{2} \mathrm{~N}$. 

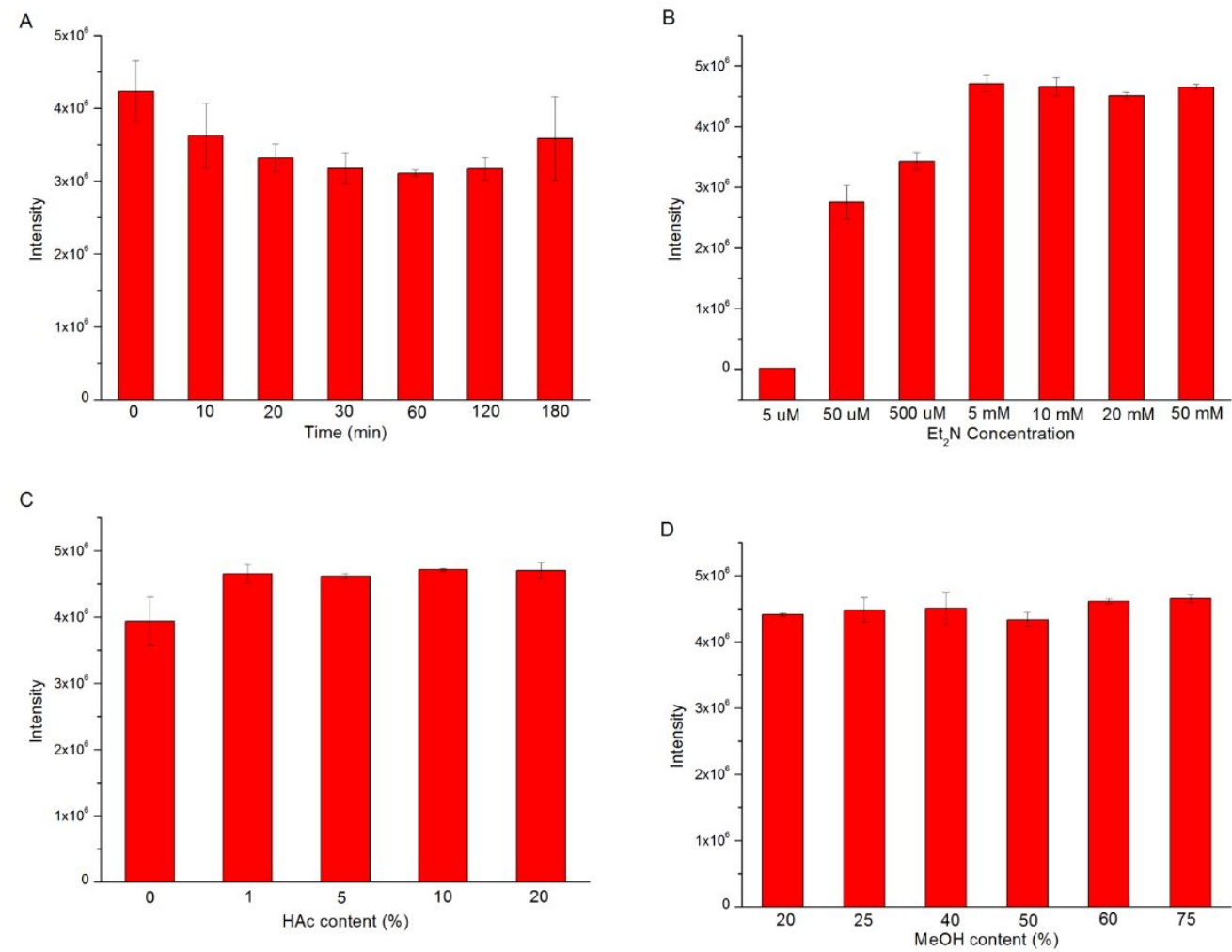

Figure S2 Optimization of derivatization conditions for $5 \mathrm{fC}$ by $\mathrm{Et}_{2} \mathrm{~N}$. The effects of $(\mathrm{A})$ reaction time, (B) $\mathrm{Et}_{2} \mathrm{~N}$ concentration, (C) $\mathrm{HAc}$ content, and (D) $\mathrm{MeOH}$ content on the derivatization efficiency of $5 f C$. 

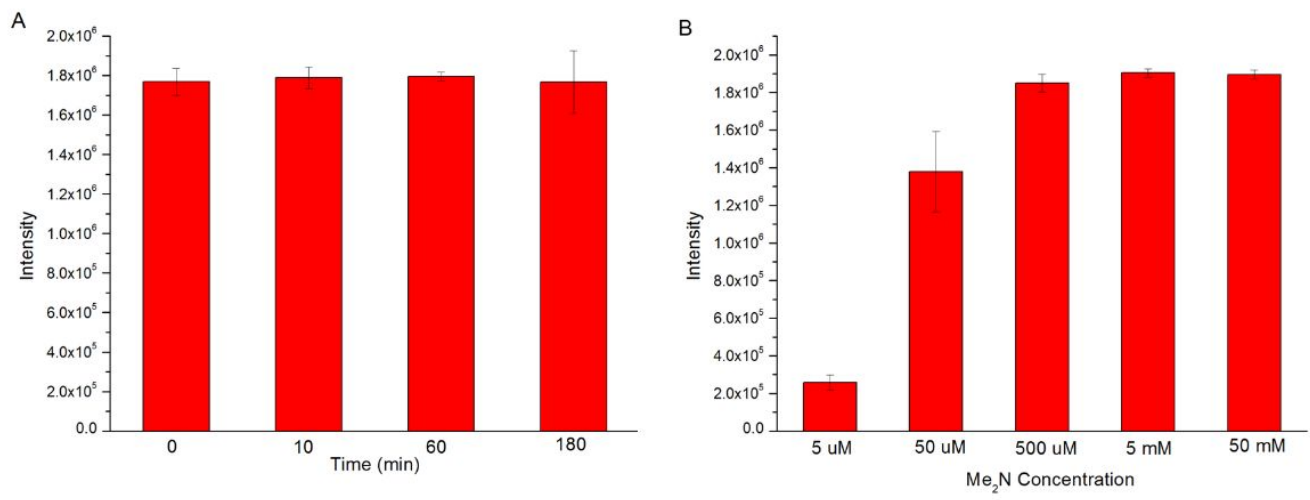

Figure S3 Optimization of derivatization conditions for $5 \mathrm{fC}$ by $\mathrm{Me}_{2} \mathrm{~N}$. The effects of $(\mathrm{A})$ reaction time and $(\mathrm{B}) \mathrm{Me}_{2} \mathrm{~N}$ concentration on the derivatization efficiency of $5 \mathrm{fC}$. 

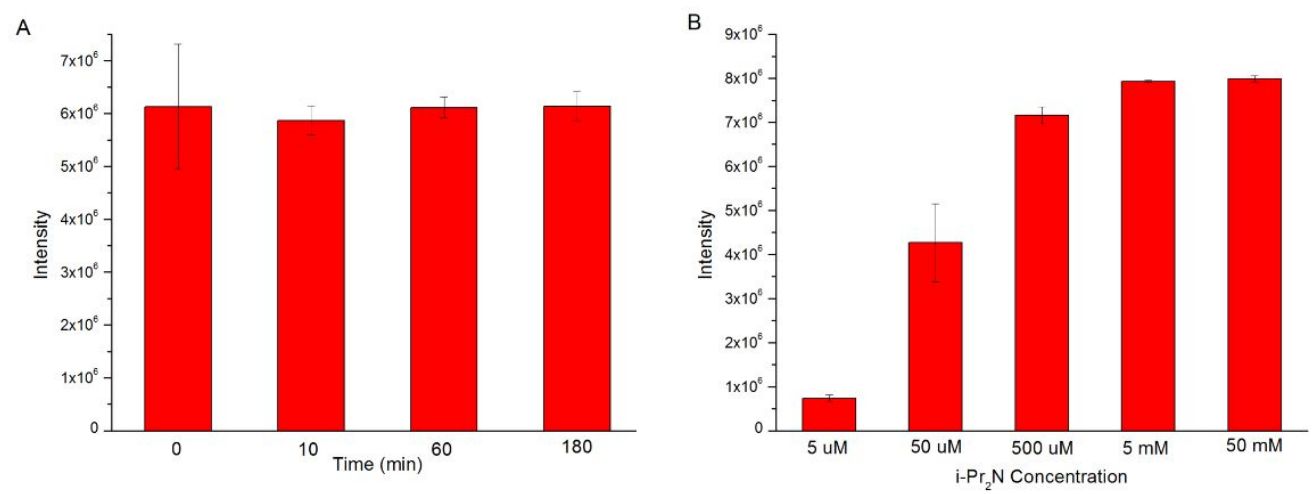

Figure S4 Optimization of derivatization conditions for $5 f C$ by i- $\mathrm{Pr}_{2} \mathrm{~N}$. The effects of $(\mathrm{A})$ reaction time and $(B) \mathrm{i}-\mathrm{Pr}_{2} \mathrm{~N}$ concentration on the derivatization efficiency of $5 \mathrm{fC}$. 

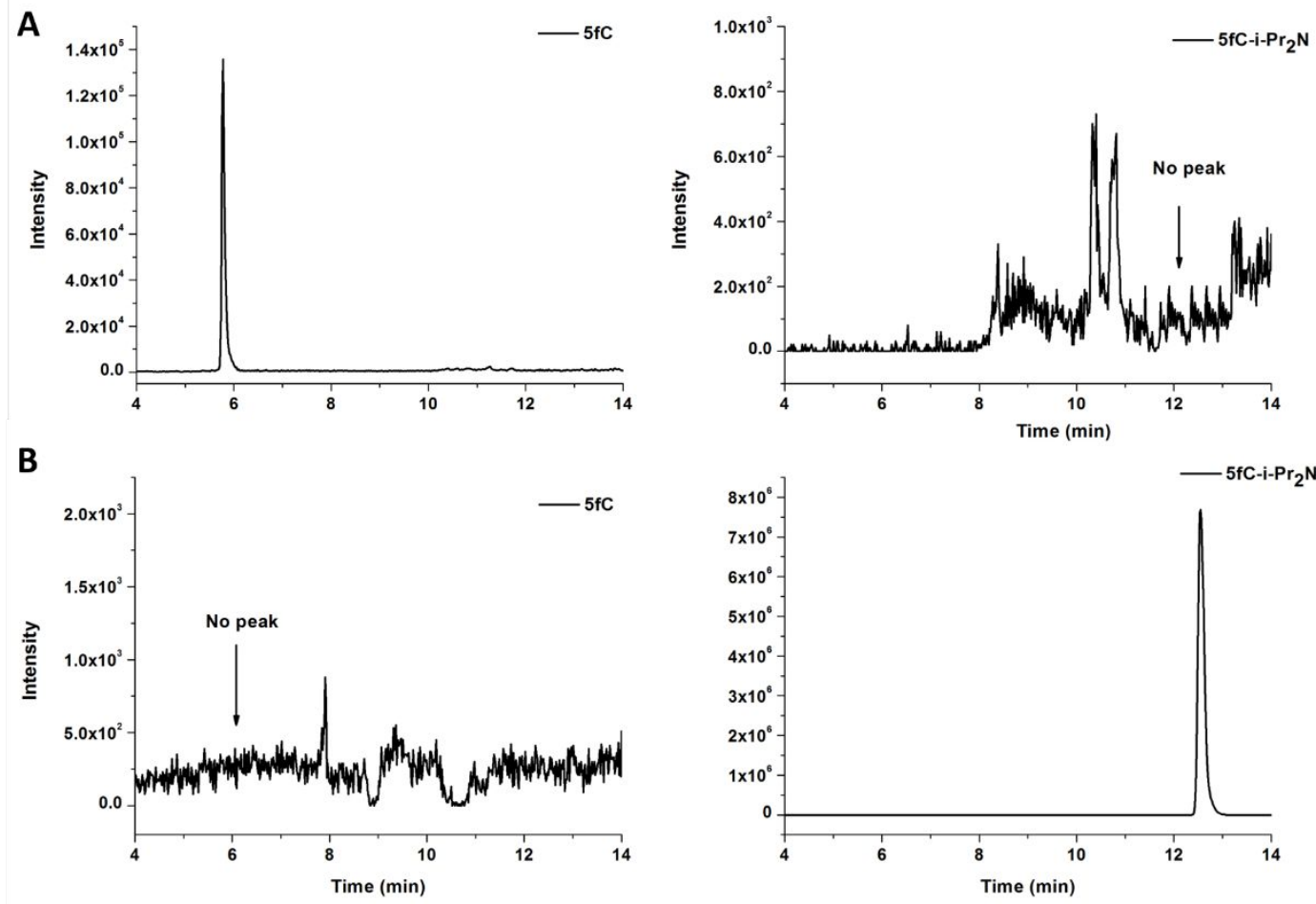

Figure S5 Extracted ion chromatograms of $5 f C$ and $5 f C-i-\operatorname{Pr}_{2} N(A)$ before and $(B)$ after labelling. The amount of $5 \mathrm{fC}$ was $250 \mathrm{fmol}$ before labelling. The peak of $5 \mathrm{fC}-\mathrm{i}-\mathrm{Pr}_{2} \mathrm{~N}$ after labelling was observed and the peak of $5 \mathrm{fC}$ was disappeared (the LOD of $5 \mathrm{fC}$ was $1.25 \mathrm{fmol}$ ), indicating that more than $99 \%$ of $5 \mathrm{fC}$ had been reacted. 

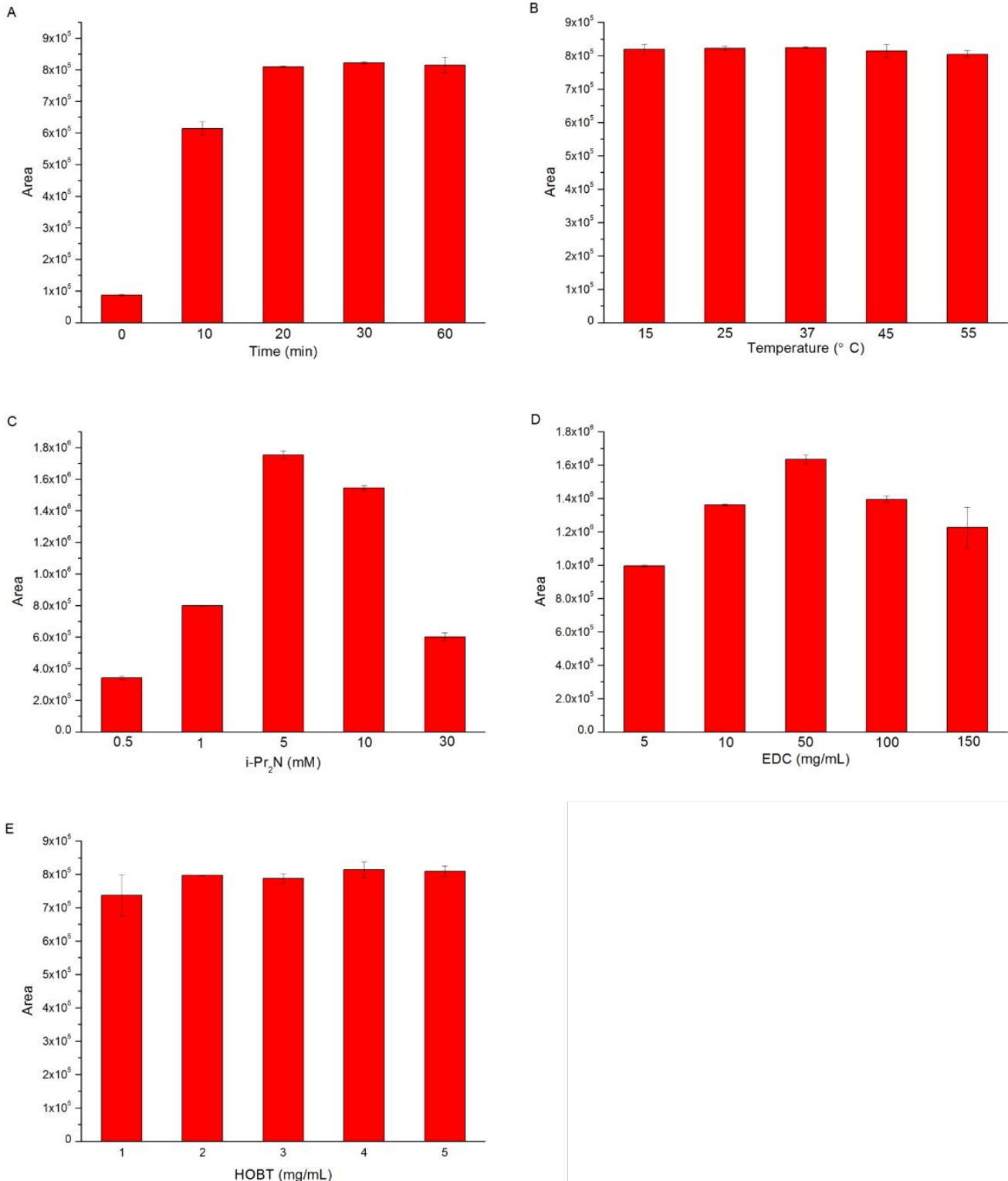

Figure S6 Optimization of derivatization conditions for $5 \mathrm{caC}$ by $\mathrm{i}-\mathrm{Pr}_{2} \mathrm{~N}$. The effects of $(\mathrm{A})$ reaction time, (B) reaction temperature, (C) $\mathrm{i}-\mathrm{Pr}_{2} \mathrm{~N}$ concentration, (D) EDC concentration and (E) HOBT concentration on the derivatization efficiency of $5 \mathrm{caC}$. 


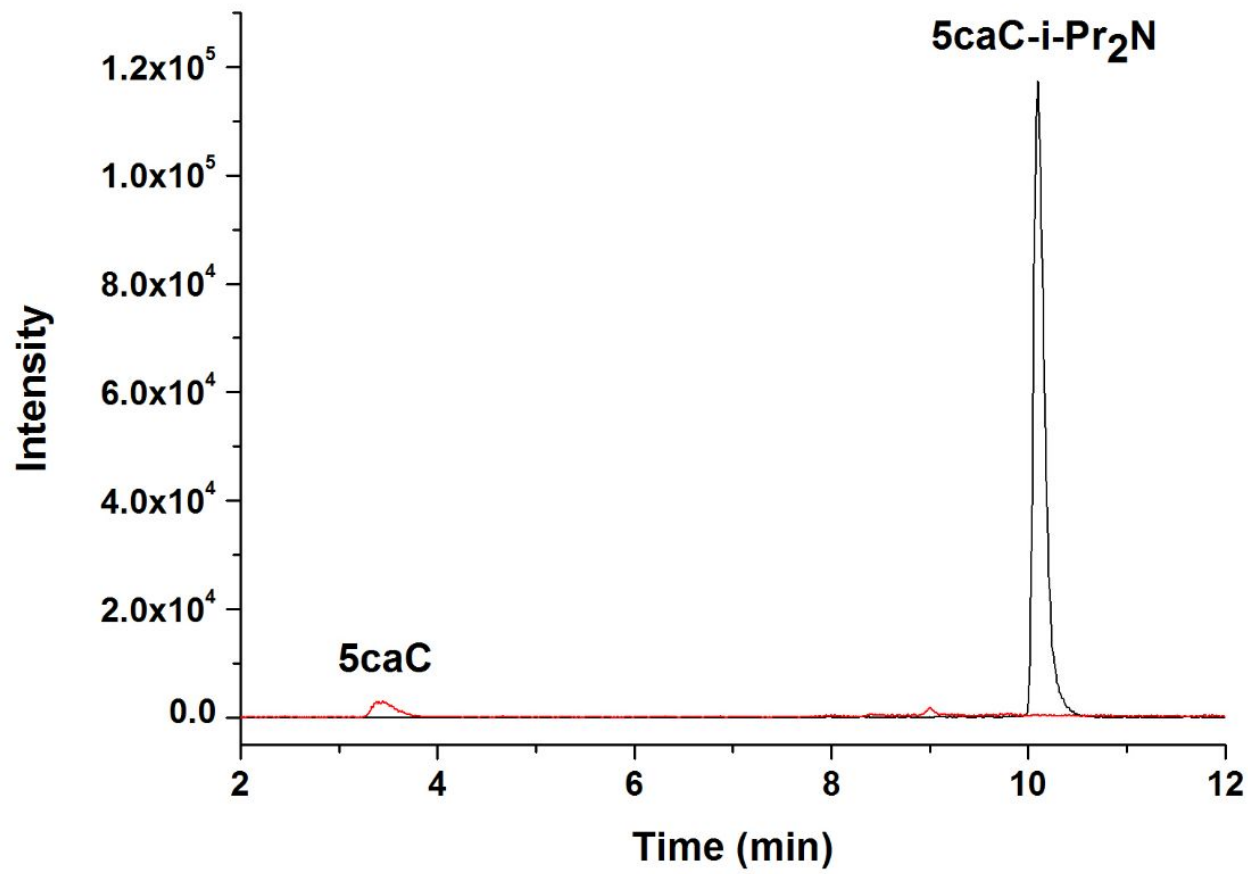

Figure S7 Extracted ion chromatograms of $5 \mathrm{caC}$ and $5 \mathrm{caC}-\mathrm{i}-\mathrm{Pr}_{2} \mathrm{~N}$ under the optimized conditions. The amounts of $5 \mathrm{caC}$ and $5 \mathrm{caC}-\mathrm{i}-\mathrm{Pr}_{2} \mathrm{~N}$ were $5 \mathrm{fmol}$, respectively. 


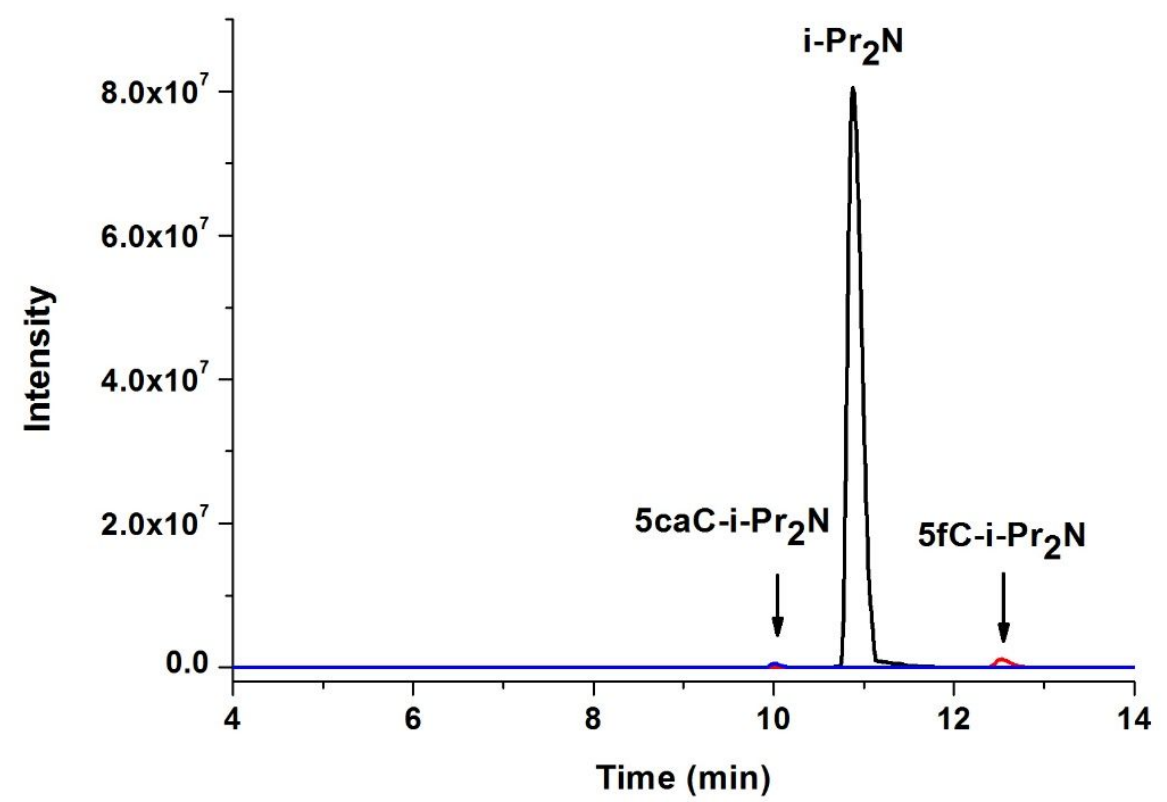

Figure S8 Extracted ion chromatograms of $\mathrm{i}-\mathrm{Pr}_{2} \mathrm{~N}, 5 \mathrm{fC}-\mathrm{i}-\mathrm{Pr}_{2} \mathrm{~N}$ and $5 \mathrm{caC}-\mathrm{i}-\mathrm{Pr}_{2} \mathrm{~N}$. The amounts of $5 \mathrm{fC}-\mathrm{i}-\mathrm{Pr}_{2} \mathrm{~N}$ and $5 \mathrm{caC}$-i- $-\mathrm{Pr}_{2} \mathrm{~N}$ were $25 \mathrm{fmol}$ and $5 \mathrm{fmol}$, respectively. 

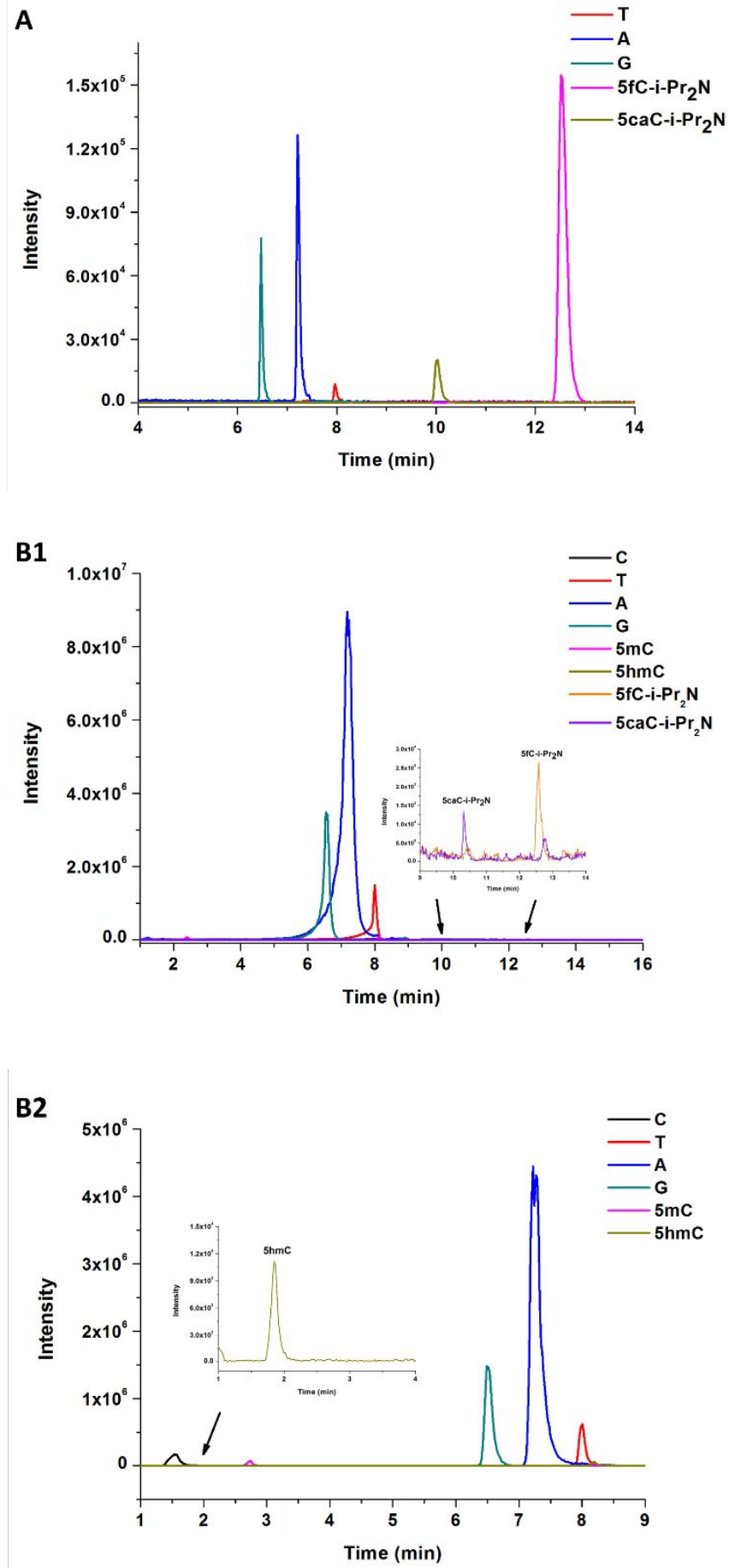

Figure S9 (A) Extracted ion chromatograms of the mixture of oligodeoxynucleotides containing $5 \mathrm{fC}$ and $5 \mathrm{caC}$. (B1) Extracted ion chromatograms of $607 \mathrm{ng}$ DNA extracted from mES cells for the detection of $5 \mathrm{fC}$ and $5 \mathrm{caC}$. (B2) Extracted ion chromatograms of mES cells diluted 10 times for the detection of other nucleotides such as $\mathrm{G}, \mathrm{C}, 5 \mathrm{mC}$ and $5 \mathrm{hmC}$. 

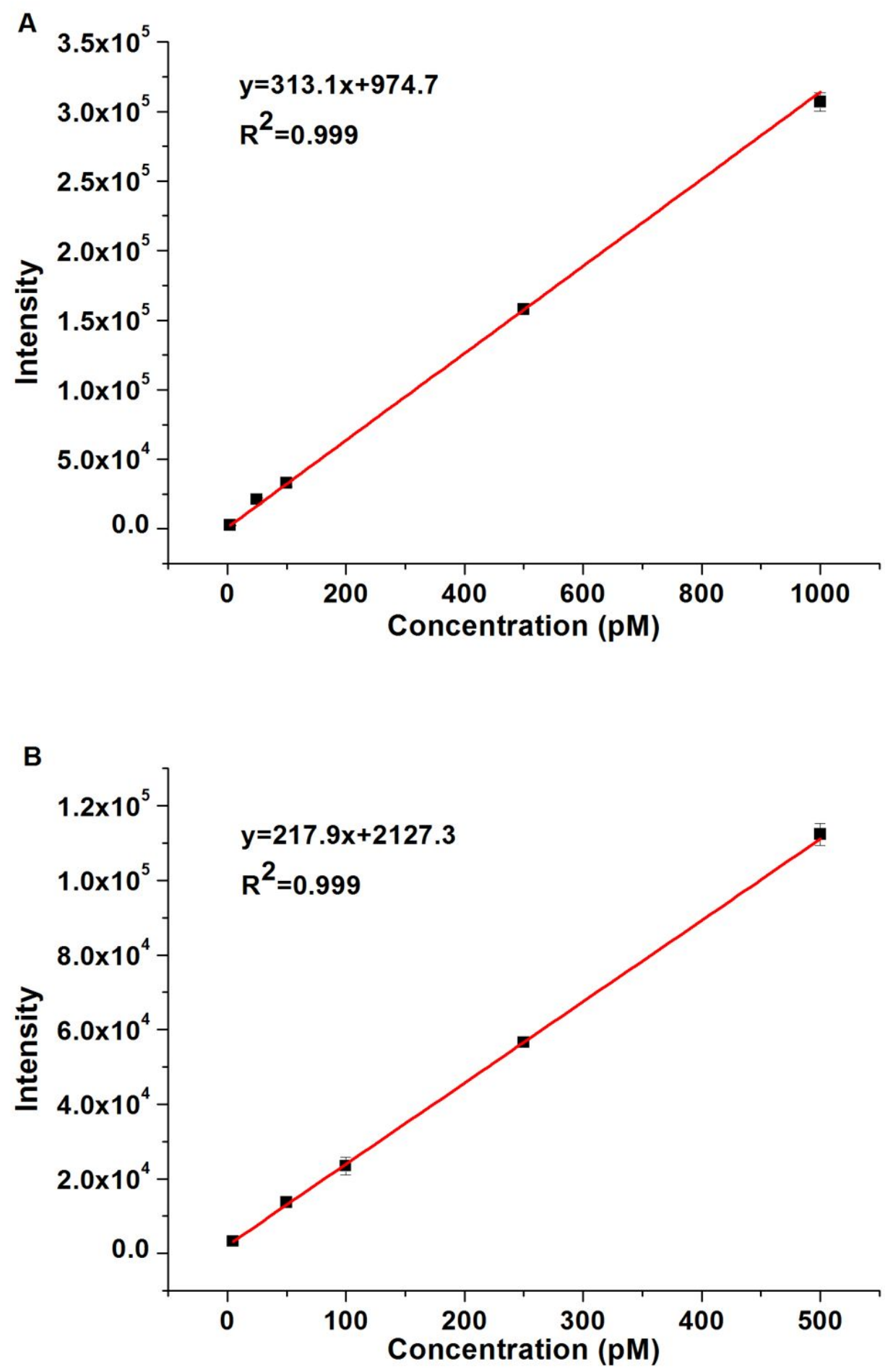

Figure S10 Calibration curves of (A) $5 \mathrm{fC}$ and (B) $5 \mathrm{caC}$ on the oligodeoxynucleotide labelled by $\mathrm{i}-\mathrm{Pr}_{2} \mathrm{~N}$. Error bars represent SD of three independent analysis. RSD $<10 \%$. 


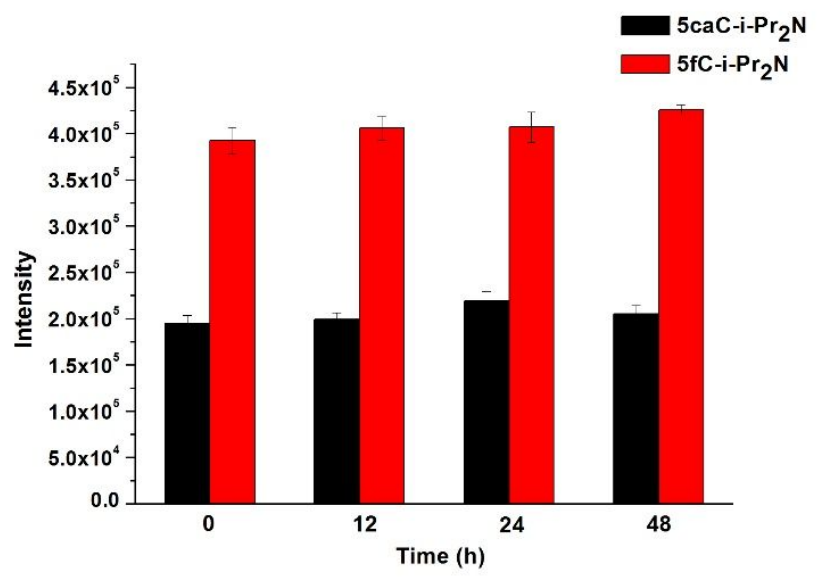

Figure $\mathrm{S} 11$ The stability of $5 \mathrm{fC}-\mathrm{i}-\mathrm{Pr}_{2} \mathrm{~N}$ and $5 \mathrm{caC}-\mathrm{i}-\mathrm{Pr}_{2} \mathrm{~N}$. 

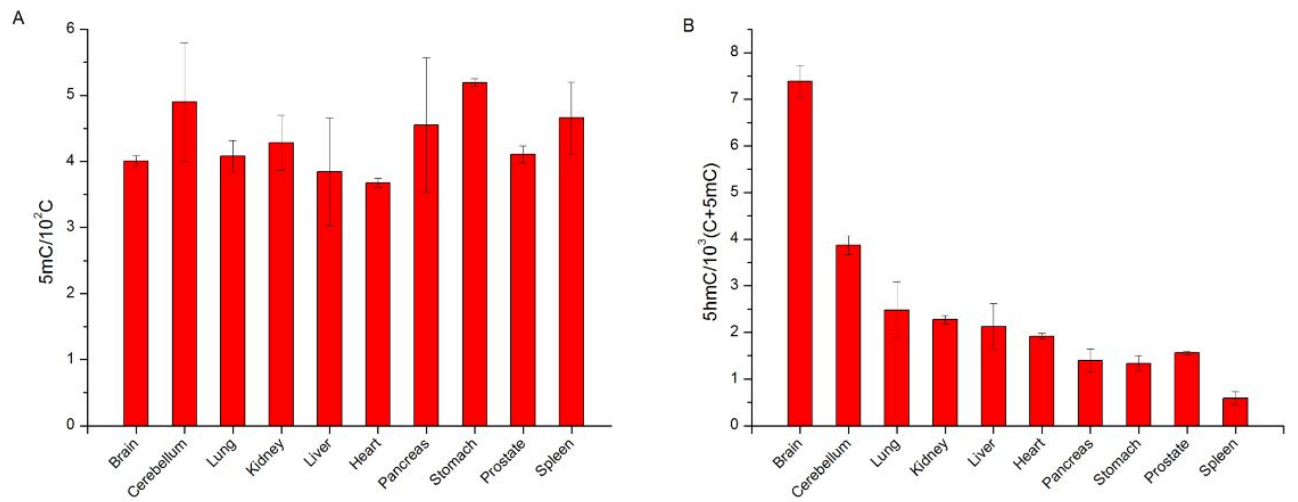

Figure S12 Quantification of (A) $5 \mathrm{mC}$ and (B) $5 \mathrm{hmC}$ in mouse tissue. The data represent the average of three independent experiments with three different mice (Table S6).

\section{References}

(1) Ito, S.; Shen, L.; Dai, Q.; Wu, S. C.; Collins, L. B.; Swenberg, J. A.; He, C.; Zhang, Y. Science 2011, 333, 1300-1303.

(2) Liu, S.; Wang, J.; Su, Y.; Guerrero, C.; Zeng, Y.; Mitra, D.; Brooks, P. J.; Fisher, D. E.; Song, H.; Wang, Y. Nucleic Acids Res 2013, 41, 6421-6429.

(3) Tang, Y.; Zheng, S. J.; Qi, C. B.; Feng, Y. Q.; Yuan, B. F. Anal Chem 2015, 87, 3445-3452.

(4) Gackowski, D.; Starczak, M.; Zarakowska, E.; Modrzejewska, M.; Szpila, A.; Banaszkiewicz, Z.; Olinski, R. Anal Chem 2016, 88, 12128-12136. 